\title{
Deficiency in EP4 Receptor-Associated Protein Ameliorates Abnormal Anxiety-Like Behavior and Brain Inflammation in a Mouse Model of Alzheimer Disease
}

\author{
Risako Fujikawa, ${ }^{\star \dagger}$ Sei Higuchi, ${ }^{*}$ Masato Nakatsuji, ${ }^{\ddagger}$ Mika Yasui, ${ }^{*}$ Taichi Ikedo, ${ }^{\star \S}$ Manabu Nagata, ${ }^{\star \S}$ Kosuke Hayashi, ${ }^{\star \S}$ \\ Masayuki Yokode, ${ }^{*}$ and Manabu Minami*
}

From the Departments of Clinical Innovative Medicine, ${ }^{*}$ Neurosurgery, ${ }^{\dagger}$ and Gastroenterology and Hepatology, ${ }^{\ddagger}$ Kyoto University Graduate School of Medicine, Kyoto; and the Japan Society for the Promotion of Science, ${ }^{\S}$ Tokyo, Japan

Accepted for publication

April 26, 2017.

Address correspondence to Manabu Minami, M.D., Ph.D., Department of Clinical Innovative Medicine, Kyoto University Graduate School of Medicine, 54 Kawahara-cho, Shogoin, Sakyo-ku, Kyoto 606-8507, Japan. E-mail: mminami@kuhp.kyoto-u.ac.jp.

\begin{abstract}
Microglia are thought to play key roles in the progression of Alzheimer disease (AD). Overactivated microglia produce proinflammatory cytokines, such as tumor necrosis factor- $\alpha$, which appear to contribute to disease progression. Previously, we reported that prostaglandin $E_{2}$ type 4 receptor-associated protein (EPRAP) promotes microglial activation. We crossed human amyloid precursor protein transgenic mice from strain $\mathrm{J}_{20} \mathrm{O}^{+/-}$onto an EPRAP-deficient background to determine the role of EPRAP in AD. Behavioral tests were performed in 5-month-old male $\mathrm{J}^{2} \mathrm{O}^{+/-} \mathrm{EPRAP}^{+/+}$and $\mathrm{J}^{20^{+/-}} \mathrm{EPRAP}^{-/-}$mice. EPRAP deficiency reversed the reduced anxiety of $\mathrm{J}^{20^{+/-}}$mice but did not affect hyperactivity. No differences in spatial memory were observed between ${\mathrm{J} 20^{+/-}}^{-E_{P R A P}^{+/+}}$and $\mathrm{J}^{20^{+/-}}$EPRAP $^{-/-}$mice. In comparison with $\mathrm{J}_{20} \mathrm{O}^{+/-} \mathrm{EPRAP}^{+/+}$, $\mathrm{J}^{2} \mathrm{O}^{+/-}$EPRAP $^{-/-}$mice exhibited less microglial accumulation and reductions in the Cd68 and tumor necrosis factor- $\alpha$ mRNAs in the prefrontal cortex and hippocampus. No significant differences were found between the two types of mice in the amount of amyloid- $\beta 40$ or 42 in the cortex and hippocampus. $\mathrm{J}^{2} \mathrm{O}^{+/-}$EPRAP $^{-/-}$mice reversed the reduced anxiety-like behavior and had reduced microglial activation compared with $\mathrm{J}_{20} \mathrm{O}^{+/-} \mathrm{EPRAP}^{+/+}$mice. Further research is required to identify the role of EPRAP in AD, but our results indicate that EPRAP may be related to behavioral and psychological symptoms of dementia and inflammation in patients with AD. (Am J Pathol 2017, 187: 1848-1854; http://dx.doi.org/10.1016/ j.ajpath.2017.04.010)
\end{abstract}

Alzheimer disease (AD), which affects approximately 48 million people around the world, results in memory loss, language difficulties, disorientation, mood swings, poor self-care, and behavioral issues that become increasingly severe as the disease advances. ${ }^{1,2}$ Abnormal accumulation of amyloid- $\beta(A \beta)$ released from amyloid precursor protein (APP) is a pathologic hallmark of AD. In addition to direct neuronal injury, accumulation of $A \beta$ also causes indirect injury to neurons by inducing brain inflammation. Microglia, the resident innate immune cells in the brain, are thought to play important roles in a number of neurodegenerative disorders, including $\mathrm{AD}$, with microglial activation increasing as the disease progresses. ${ }^{1}$ Although multiple studies have proposed that microglia are legitimate therapeutic targets, ${ }^{2}$ the molecular mechanisms that govern microglial activation remain poorly understood.
Prostaglandin $\mathrm{E}_{2}$ type 4 (EP4) receptor-associated protein (EPRAP) is a cytoplasmic signaling partner of EP4. ${ }^{3}$ In mice, EPRAP is also known as Fem1a, an ortholog of Caenorhabditis elegans FEM-1 that participates in sex determination. ${ }^{4}$ Recently, a study that involved EPRAPdeficient $\left(\right.$ EPRAP $^{-1-}$ ) mice $^{5}$ found that EPRAP is present in wild-type microglia and that microglial EPRAP promotes inflammation in the brain. In particular, EPRAP deficiency decreases microglial activation in mice treated with lipopolysaccharide or kainic acid. Application of an EP4 agonist to microglia results in increased uptake of $\mathrm{A} \beta,{ }^{6}$ although

Supported in part by Japan Society for the Promotion of Science grants 23590361 and 26460338 (M.M.), 15K08230 (M.Y.), and 820140600019 (R.F.).

Disclosures: None declared. 
little is known regarding the contribution of EPRAP in neurodegenerative disorders. In this study, we examined the role of EPRAP in the pathogenesis of AD using AD model h-APPJ20 $\left(\mathrm{J}^{2} 0^{+/-}\right) \mathrm{EPRAP}^{+/+}$mice and J20 ${ }^{+/-} \mathrm{EPRAP}^{-/-}$ compound mutant mice to determine whether EPRAP suppresses microglial activation and $A \beta$ accumulation.

\section{Materials and Methods}

\section{Experimental Animals}

EPRAP-deficient (EPRAP ${ }^{-1-}$ ) mice on a congenic C57BL/ 6 background were generated as previously described. ${ }^{7}$ $\mathrm{J} 20^{+/-}$mice, which express a mutant form of human APP bearing both the Swedish (K670N/M671L) and the Indiana (V717F) mutations (APPSwInd), ${ }^{8}$ as well as wild-type $\left(\mathrm{EPRAP}^{+/+}\right.$) C57BL/6 mice, were from Charles River Laboratories Japan (Yokohama, Japan). We crossed J20 ${ }^{+/-}$ mice onto an EPRAP-deficient background. The genetic background of $\mathrm{J} 20^{+/-}$mice is C57BL/6, same as that of EPRAP $^{-1-}$ mice. $\mathrm{J}^{+0^{+/}}$EPRAP $^{+/+}$and $\mathrm{J}^{20^{+/}}$EPRAP $^{-/-}$ mice were bred as littermates. In one cage, there were four mice: an EPRAP ${ }^{+/+}$mouse, an EPRAP ${ }^{-l-}$ mouse, a J $20^{+/-}$ EPRAP $^{+/+}$mouse, and a $\mathrm{J}^{2} 0^{+/-} \mathrm{EPRAP}^{-/-}$mouse. Male mice 5 to 8 months old were used for all experiments. For immunohistologic assessment, murine brains were sliced and stained with antibodies against ionized calcium-binding adaptor molecule (Iba)-1 (Wako Pure Chemical Industries, Osaka, Japan). All experiments and animal care were conducted following the guidelines for the Japan's Act on Welfare and Management of Animals (Act no. 105 of October 1, 1973). These studies were approved by the Institutional Animal Care and Use Committees and the ethics committee of Kyoto University (permit number: MedKyo15183).

\section{Behavioral Tests}

Behavioral tests were performed between 9:00 AM and 4:00 PM. Neuromuscular strength was tested using a grip strength meter (O'Hara \& Co., Tokyo, Japan). Anxiety was evaluated using a light/dark transition box (O'Hara \& Co.) and an elevated plus maze (O'Hara \& Co.). Spatial memory was tested using a Barnes maze (O'Hara \& Co.). All tests were conducted as previously described. ${ }^{9}$

\section{Total RNA Extraction and Quantitative Real-Time PCR}

Total RNA was extracted using the RNeasy Mini Kit (Qiagen, Valencia, CA) and reverse transcribed using the High-Capacity cDNA Reverse Transcription kit (Applied Biosystems, Forster City, CA). mRNA levels of proinflammatory cytokines in the cerebral cortices were measured. The following primers were used: mouse $\beta$-actin, forward 5'-CCTGAGCGCAAGTACTCTGTGT-3' and reverse 5'-GCTGATCCACATCTGCTGGAA-3'; Cd68, forward $5^{\prime}$-CTTCCCACAGGCAGCACAG- $3^{\prime}$ and reverse $5^{\prime}$-AATGATGAGAGGCAGCAAGAGG- $3^{\prime}$; and tumor necrosis factor (Tnf)- $\alpha$, forward $5^{\prime}$-CATCTTCTCAAAATTCGAGTGACAA- $3^{\prime}$ and reverse 5'-TGGGAGTAGACAAGGTACAACCC- $3^{\prime}$. All experiments were performed in duplicate, and results were normalized using $\beta$-actin as a reference gene.

\section{Enzyme-Linked Immunosorbent Assay}

A $\beta 40$ and 42 in radioimmunoprecipitation assay lysis buffer-soluble fractions of brain homogenates were quantified using the human $A \beta$ (1 to 40) and human $A \beta$ (1 to 42) enzyme-linked immunosorbent assay kits (Wako Pure Chemical Industries).

\section{Statistical Analysis}

Results are expressed as means \pm SEM. The $t$-test and the Tukey-Kramer test were used to determine statistically significant differences. $P<0.05$ was considered statistically significant.

\section{Results}

\section{$\mathrm{J}^{2} 0^{+/-}$EPRAP $^{-/-}$Mice Are Generally Healthy}

The $\mathrm{J} 20^{+/-}$mouse, which overexpresses human APP with two mutations linked to familial $\mathrm{AD}$, is one of the most widely used models of $\mathrm{AD}$. Brain inflammation and behavioral abnormalities in $\mathrm{J} 20^{+/-}$mice arise by 5 to 7 months of age. ${ }^{10} \mathrm{We}$ generated $\mathrm{J}_{20} \mathrm{O}^{+/-} \mathrm{EPRAP}^{-/-}$compound mutant mice and

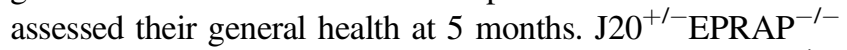
mice exhibited lower body weight than wild-type $\left(\mathrm{EPRAP}^{+/+}\right)$ mice, although body weight did not differ between $\mathrm{J}^{+0^{+/}}$ EPRAP $^{-/-}$mice and $\mathrm{J}^{20^{+/-}} \mathrm{EPRAP}^{+/+}$mice (Figure 1A). No significant differences were observed in grip strength (Figure 1B). J20 ${ }^{+/-}$EPRAP $^{-1-}$ mice exhibited no other abnormalities in body temperature, neuronal alignment in the brain, or other features (data not shown).

\section{EPRAP Deficiency Decreases Abnormal Anxiety-Like Behavior in $\mathrm{J}^{+} \mathrm{O}^{+/-}$Mice}

Several studies reported that $\mathrm{J} 20^{+/-}$mice exhibit behavioral and psychological symptoms of dementia (BPSD), including reduced anxiety and increased hyperactivity, similar to other human APP transgenic mice. ${ }^{11,12}$ As previously reported, EPRAP regulates inflammatory activation of microglia, so it could contribute to BPSD associated with brain inflammation in $\mathrm{AD} .{ }^{13}$ To determine whether EPRAP is involved in such behavioral abnormalities, we assessed anxiety-like behavior and motor activity in $\mathrm{EPRAP}^{+/+}$, $\mathrm{EPRAP}^{-/-}, \mathrm{J} 20^{+/-} \mathrm{EPRAP}^{+/+}$, and $\mathrm{J} 20^{+/-} \mathrm{EPRAP}^{-/-}$mice using the light/dark transition test and elevated plus maze, 

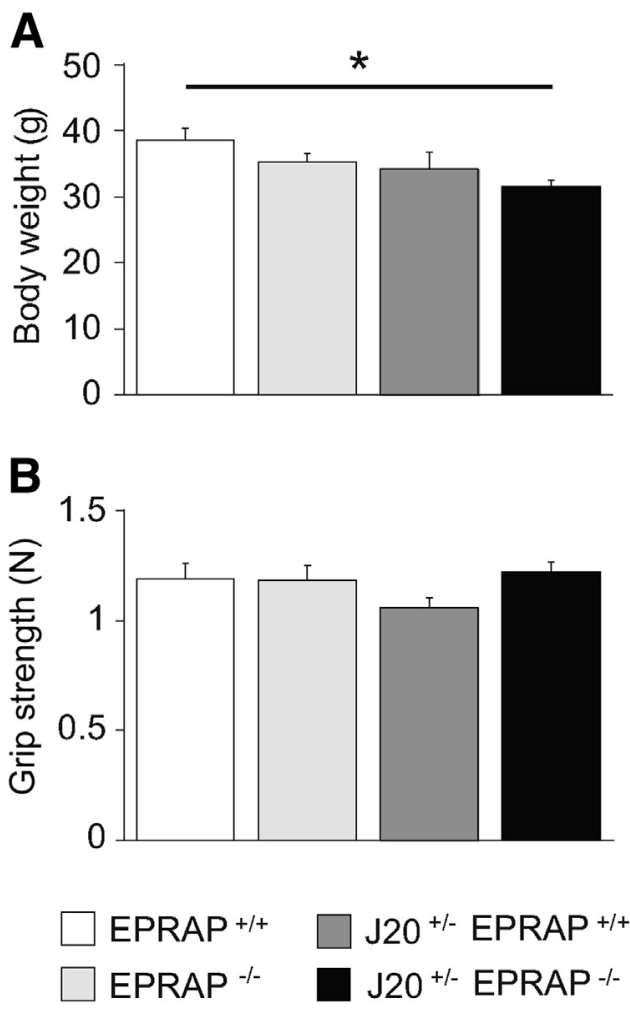

Figure 1 Prostaglandin $E_{2}$ type 4 receptor-associated protein (EPRAP) deficiency does not affect general health in $\mathrm{J}_{20} \mathrm{O}^{+-}$mice. A: Body weight. B: Neuromuscular strength, as evaluated using the grip strength test. Data are expressed as means \pm SEM. $n=10$ for each group. ${ }^{*} P<0.05$. EPRAP $^{-1-}$, EPRAP knockout; EPRAP $^{+/+}$, wild-type EPRAP; J20 ${ }^{+/-}$EPRAP $^{+/+}, \mathrm{J} 20$ transgenic with wild-type EPRAP; J20 ${ }^{+/-} \mathrm{EPRAP}^{-/-}, \mathrm{J} 20$ transgenic with EPRAP knockout.

which are the tests most commonly used for this purpose in mice.

The light/dark transition test is based on the natural aversion of mice to brightly illuminated areas: anxious mice spend less time in the light box. In this study, $\mathrm{J} 20^{+/-}$ EPRAP $^{+/+}$mice tended to remain in the light compartment longer than $\mathrm{EPRAP}^{+/+}$and $\mathrm{EPRAP}^{-/-}$mice (Figure 2A), indicating lower levels of anxiety. By contrast, stay time in the light box was significantly reduced in $\mathrm{J}_{20} 0^{+-} \mathrm{EPRAP}^{-\prime-}$ mice relative to $\mathrm{J}^{2} 0^{+/-} \mathrm{EPRAP}^{+/+}$mice, comparable to the stay times of $\mathrm{EPRAP}^{+/+}$and $\mathrm{EPRAP}^{-/-}$mice (Figure 2A). Next, we measured total distance traveled in the light/dark transition test to assess levels of motor activity in each group.

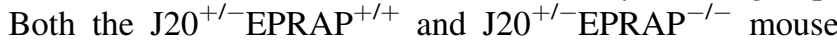
groups exhibited hyperactivity (Figure $2 \mathrm{~B}$ ).

The elevated plus maze test is based on the natural aversion of mice for open and elevated areas, with anxious mice spending less time on the open arm than nonanxious mice. $\mathrm{J}^{2} 0^{+/} \mathrm{EPRAP}^{+/+}$mice stayed on the open arm longer than the $\mathrm{EPRAP}^{+/+}$and $\mathrm{EPRAP}^{-/-}$mice (Figure 2C), indicating lower levels of anxiety. No significant differences were observed between $\mathrm{J}_{20} 0^{+/} \mathrm{EPRAP}^{-/-}$mice and the remaining groups with regard to performance in this test
(Figure 2C), whereas both $\mathrm{J} 20^{+/-} \mathrm{EPRAP}^{+/+}$and $\mathrm{J} 20^{+/-}$ $\mathrm{EPRAP}^{-1-}$ mice traveled greater distances, indicating hyperactivity (Figure 2D). These results suggest that EPRAP deficiency reversed the reduced anxiety but did not affect hyperactivity in $\mathrm{J} 20^{+/-}$mice.

\section{EPRAP Deficiency Does Not Affect Spatial Memory Deficit in $\mathrm{J}^{2} 0^{+/-}$Mice}

$\mathrm{J} 20^{+/-}$mice exhibit increasing deficits in spatial memory as they age. ${ }^{14,15}$ In this study, we assessed spatial memory using the Barnes maze. During training, we observed no differences in the learning patterns of $\mathrm{J}_{2} \mathrm{O}^{+/-} \mathrm{EPRAP}^{+/+}$and $\mathrm{J}^{2} 0^{+/-}$EPRAP $^{-1-}$ mice (data not shown). Spatial memory was assessed 1 week (probe test 1) and 1 month (probe test 2) after the last training to investigate the role of EPRAP in short- and long-term memory, respectively. After the platform was removed, mice were allowed to explore the maze board. Time spent in the correct hole during probe tests 1 and 2 tended to decrease for both $\mathrm{J}_{20}{ }^{+/-} \mathrm{EPRAP}^{+/+}$ and $\mathrm{J}_{20}{ }^{+/-} \mathrm{EPRAP}^{-/-}$mice relative to $\mathrm{EPRAP}^{+/+}$mice (Figure 2, E and F). No significant differences in time spent around the correct hole during probe tests 1 and 2 were observed between $\mathrm{J}_{20}{ }^{+/-} \mathrm{EPRAP}^{+/+}$and $\mathrm{J} 20^{+/} \mathrm{EPRAP}^{-/-}$ mice (Figure 2, E and F). These results suggest that EPRAP deficiency did not prevent spatial memory deficits in $\mathrm{J} 20^{+/-}$ mice.

\section{Microglial Activation Is Suppressed in $\mathrm{J}^{20^{+/-}}$EPRAP $^{-/-}$ Mice Relative to $\mathrm{J}^{2} 0^{+/-} \mathrm{EPRAP}^{+/+}$}

To evaluate the role of EPRAP in the pathophysiology of $\mathrm{AD}$, we examined microglial activation in $\mathrm{J} 20^{+/-}$ $\mathrm{EPRAP}^{+/+}$and $\mathrm{J}^{2} 0^{+/-} \mathrm{EPRAP}^{-/-}$mice. $\mathrm{J}^{2} 0^{+/} \mathrm{EPRAP}^{-/-}$ mice exhibited less accumulation of Iba1-positive microglia in the cortex and hippocampus than $\mathrm{J}^{2} 0^{+/-} \mathrm{EPRAP}^{+/+}$mice (Figure 3, A and B). Quantitative RT-PCR analysis revealed reduced expression of Cd68 and Tnf- $\alpha$ mRNAs in the cortex and the hippocampus of $\mathrm{J}^{+/-} \mathrm{EPRAP}^{-1-}$ mice (Figure 3C), suggesting that EPRAP may promote inflammation in $\mathrm{AD}$.

\section{EPRAP Deficiency Does Not Affect the Deposition of $A \beta$}

Deposition of $A \beta$ in the brain results in neuronal injury and activation of microglia, important components of the cascade involved in pathogenic progression of $\mathrm{AD} .^{1} \mathrm{~J} 20^{+/-}$mice exhibit diffuse $A \beta$ plaque deposition in the cortex and hippocampus at 5 to 7 months. ${ }^{16}$ To clarify the role of EPRAP in the production or clearance of $A \beta$, we measured $A \beta$ using enzyme-linked immunosorbent assay. No significant difference in the amount of $A \beta 40$ and $A \beta 42$ in the cortex or hippocampus was observed between $\mathrm{J}^{+/-} \mathrm{EPRAP}^{+/+}$and

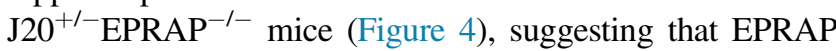
exerts little influence on production or clearance of $A \beta$. 
A

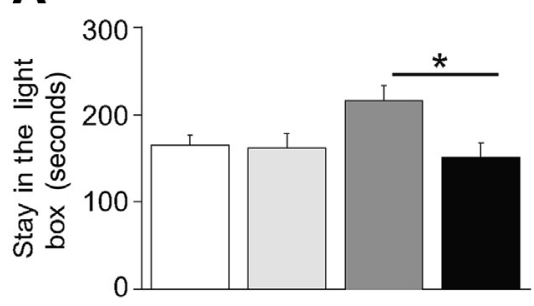

C

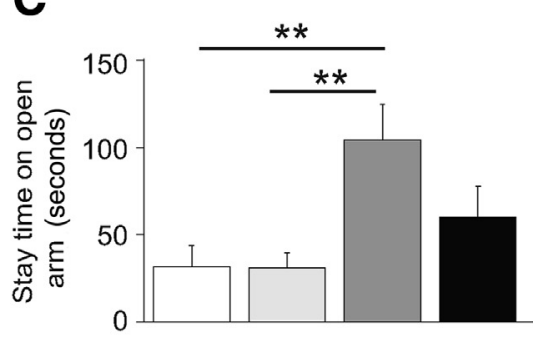

E

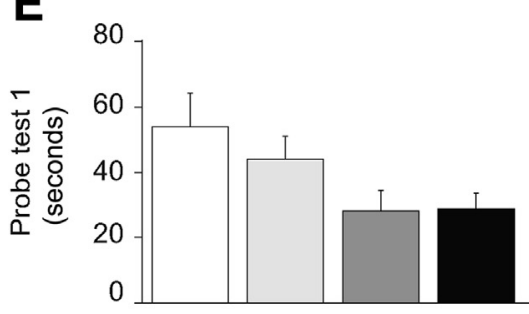

B

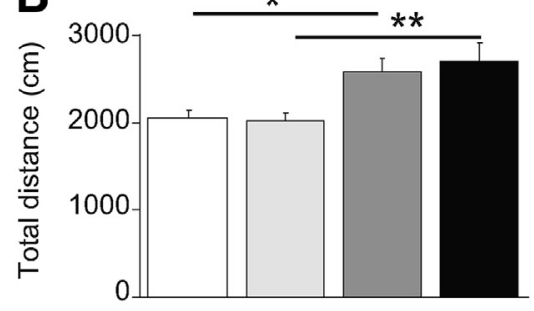

D

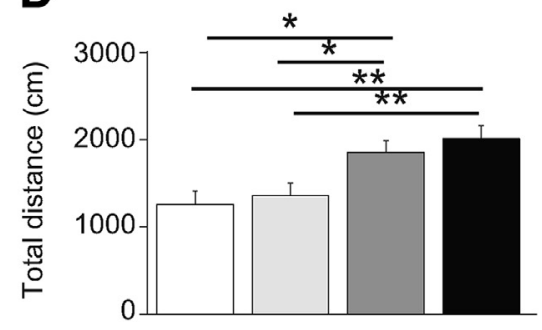

$\mathbf{F}$

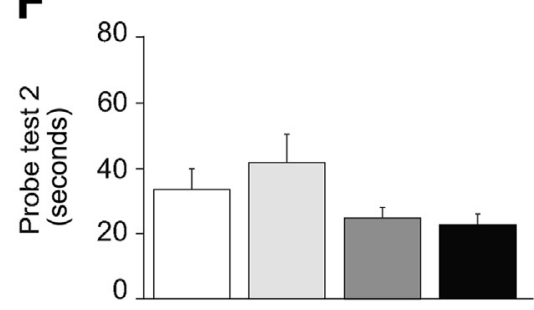

Figure 2 Prostaglandin $E_{2}$ type 4 receptorassociated protein (EPRAP) deficiency decreases abnormal anxiety-like behavior but does not affect spatial memory impairment in $\mathrm{J} 20^{+/-}$mice. $\mathbf{A}$ and $\mathbf{B}$ : Light-dark transition test. J20 ${ }^{+/-}$EPRAP $^{+/+}$mice tend to remain in the light compartment longer than $\mathrm{EPRAP}^{+/+}$mice, although no significant difference in light-compartment time is observed between

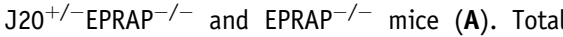
distance traveled is higher in $\mathrm{J}_{20} \mathrm{O}^{+/-} \mathrm{EPRAP}^{+/+}$and $\mathrm{J}_{20} \mathrm{O}^{+/-} \mathrm{EPRAP}^{-/-}$mice than in other mouse groups (B). C and D: Elevated plus maze test. $\mathrm{J}_{2} \mathrm{O}^{+/}$ EPRAP $^{+/+}$mice remain on the open arm longer than both $\mathrm{EPRAP}^{+/+}$and $\mathrm{EPRAP}^{-/-}$mice. No difference is observed between $\mathrm{J}^{2} \mathrm{O}^{+/-} \mathrm{EPRAP}^{-/}$mice and the remaining groups $(\mathbf{C})$. Total distance traveled is

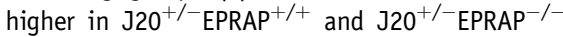
mice than in other mouse groups (D). E and $\mathbf{F}$ : Barnes maze test. Time around the correct hole during probe test 1 (1 week after initial training) (E). Time around the correct hole during probe test 2 (1 month after initial training) (F). Data are expressed as means \pm SEM. $n=10$ for each group. $P=0.07$ in $\mathrm{EPRAP}^{+/+}$versus $\mathrm{J}^{2} 0^{+/-} \mathrm{EPRAP}^{+/+} ; P=0.06$ in $\mathrm{EPRAP}^{-/-}$and $\mathrm{J} 20^{+/-} \mathrm{EPRAP}^{+/+}$; and $P=0.07$ in EPRAP $^{+/+}$versus $\mathrm{J}_{20} \mathrm{O}^{+/-} \mathrm{EPRAP}^{+/+}$and $\mathrm{EPRAP}^{+/+}$ versus $\mathrm{J}^{2} 0^{+/-}$EPRAP $^{-/-}{ }^{*}{ }^{*} P<0.05,{ }^{* *} P<0.01$. EPRAP $^{-/-}$, EPRAP knockout; $\mathrm{EPRAP}^{+/+}$, wild-type EPRAP; $\mathrm{J}_{20}^{+/-} \mathrm{EPRAP}^{+/+}, \mathrm{J} 20$ transgenic with wild-type EPRAP; $\mathrm{J}_{20} \mathrm{O}^{+/-} \mathrm{EPRAP}^{-/-}$, J20 transgenic with EPRAP knockout.

$\square$ EPRAP $^{+/+} \square$ EPRAP $^{-/} \square \mathrm{J}^{2} 0^{+/-}$EPRAP $^{+/+} \square \mathrm{J}_{2} 0^{+/-}$EPRAP $^{-/-}$

\section{Discussion}

Microglia are thought to play key roles in the pathophysiology and progression of a number of neurodegenerative disorders, including $\mathrm{AD}$, and the number of patients with $\mathrm{AD}$ is projected to nearly triple between 2010 and $2050 .{ }^{17}$ Therefore, a more detailed understanding of the mechanisms underlying microglial activation is important for the development of new therapies for AD.

Elevated levels of TNF- $\alpha$ have been detected in the plasma and brains of patients with AD. ${ }^{18}$ TNF- $\alpha$ stimulation of neuronal cells leads to increased inducible nitric oxide synthase expression and subsequent apoptosis. ${ }^{19,20}$ Previously, we reported that EPRAP promotes induction of inflammation by lipopolysaccharide via regulation of the MKK4-JNK pathways in microglia. ${ }^{5}$ Like lipopolysaccharide, $\mathrm{A} \beta$ binds directly to microglia through cell-surface receptors, such as Toll-like receptor $4 .^{21}$ In vitro analyses have revealed that microglia treated with $A \beta$ increase phosphorylation levels of $\mathrm{JNK}$, as well as production of TNF- $\alpha$. $^{22}$

Patients with AD exhibit not only memory dysfunction but also BPSD, including abnormal levels of anxiety. ${ }^{23}$ Patients with AD typically have increased anxiety but sometimes also have the opposite tendency of disinhibition. ${ }^{24}$ Antipsychotics and antidepressants have been recommended for the treatment of BPSD, ${ }^{25}$ although a recent warning by the US Food and Drug Administration regarding the elevated mortality rate of older adults taking atypical antipsychotics necessitates the development of alternative therapies. The underlying mechanism of BPSD and memory deficits may differ. Overactivated microglia may contribute to abnormal anxiety-like behavior. Several studies have observed a correlation between BPSD and cytokine levels in the cerebrospinal fluid of patients with AD. ${ }^{13}$ The serotonin system in the prefrontal cortex plays an important role in the development of anxiety. Previous in vitro studies have revealed that TNF- $\alpha$ may increase activity of the serotonin transporter-a protein involved in the termination of serotonergic signaling - via activation of p38 mitogen-activated protein kinase. ${ }^{26}$ Our data suggest that EPRAP deficiency may alleviate abnormal anxiety in $\mathrm{AD}$ by suppressing microglial activation and production of TNF- $\alpha$.

Activation of microglia by $\mathrm{A} \beta$ promotes disease progression; however, $\mathrm{A} \beta$ itself also damages neurons. ${ }^{27}$ Elevated levels of $A \beta$ lead to a reduction in long-term potentiation in the hippocampus, the most critical area for spatial memory. ${ }^{28}$ Moreover, research using neuronal cell 


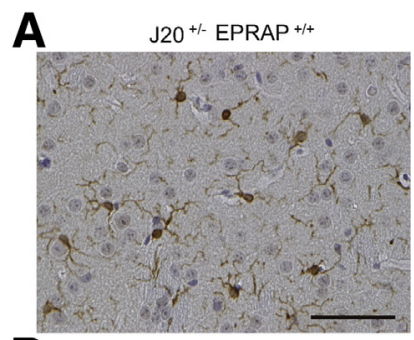

B
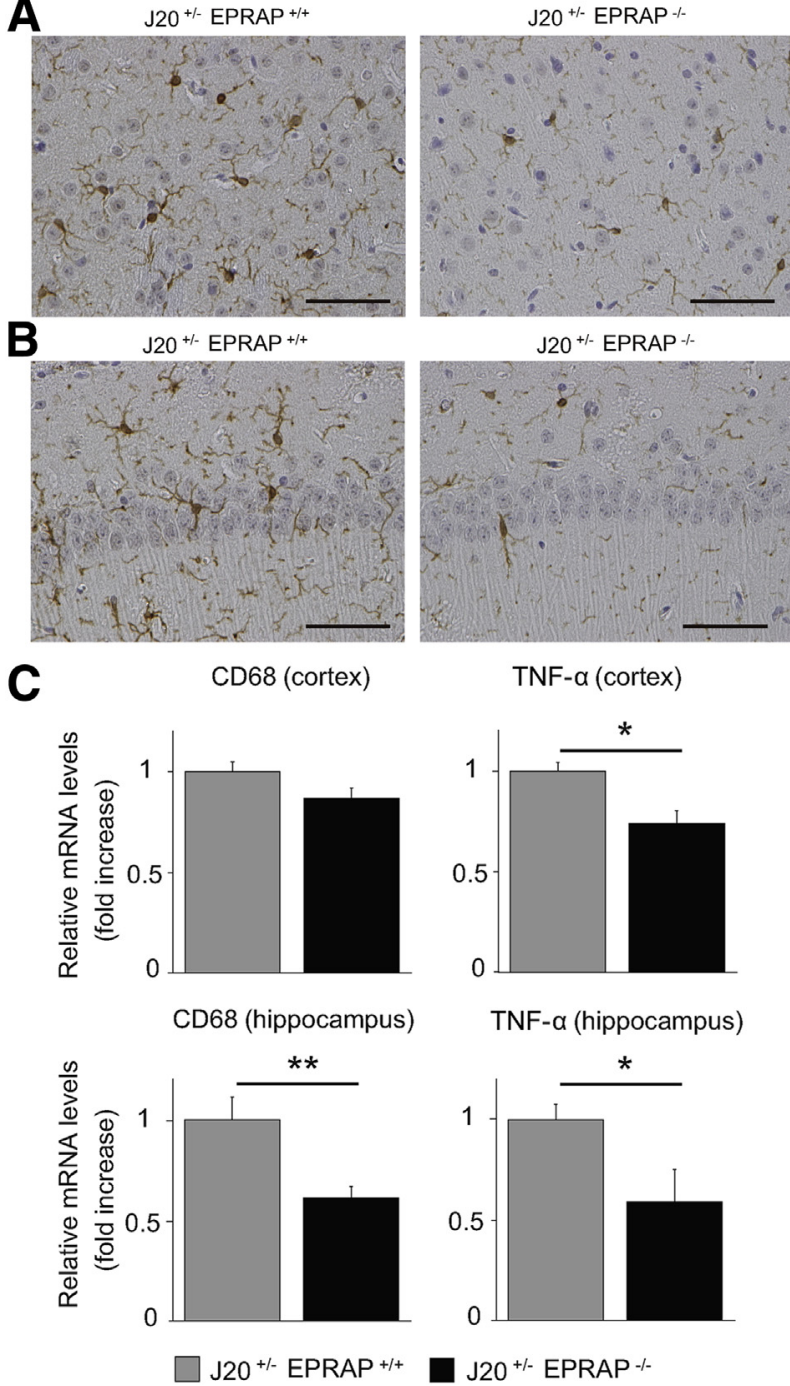

Figure 3 Prostaglandin $E_{2}$ type 4 receptor-associated protein (EPRAP) deficiency decreases microglial activation and proinflammatory cytokine expression in the brains of $\mathrm{J}_{2} \mathrm{O}^{+/-}$mice. $\mathbf{A}$ and $\mathbf{B}$ : The number of ionized calcium-binding adaptor molecule (Iba)-1 positive microglial cells is lower in the brains of $\mathrm{J}^{2} \mathrm{O}^{+/-} \mathrm{EPRAP}^{-/-}$mice than in the brains of $\mathrm{J}^{2} \mathrm{O}^{+/-} \mathrm{EPRAP}^{+/+}$ mice. Prefrontal cortex (A). Hippocampus (B). C: Levels of Cd68 and tumor necrosis factor (Tnf)- $\alpha$ mRNAs in the prefrontal cortex of $\mathrm{J}^{20^{+/-}} \mathrm{EPRAP}^{+/+}$ and $\mathrm{J}_{2} \mathrm{O}^{+/-}$EPRAP $^{-/-}$mice. The difference in CD68 mRNA levels in the cortex between $\mathrm{J}_{20} \mathrm{O}^{+/-} \mathrm{EPRAP}^{+/+}$and $\mathrm{J} 20^{+/-} \mathrm{EPRAP}^{-/-}$mice is not significant. Data are expressed as means \pm SEM. $n=6$ for each group (C). $P=0.07$. ${ }^{*} P<0.05$, ${ }^{* * P}<0.01$. Scale bars $=50 \mu \mathrm{m}(\mathbf{A}$ and $\mathbf{B})$. EPRAP $^{-/-}$, EPRAP knockout; EPRAP $^{+/+}$, wild-type EPRAP; J20 ${ }^{+/-}$EPRAP $^{+/+}, \mathrm{J} 20$ transgenic with wild-type EPRAP; J20 ${ }^{+/-}$EPRAP $^{-/-}$, J20 transgenic with EPRAP knockout.

cultures has revealed that $A \beta$ induces apoptosis of neuronal cells via oxidative stress. ${ }^{29}$ Further reductions in $A \beta$ would therefore be required to protect the hippocampal neurons that store spatial memory.

Previous studies have revealed that administration of an EP4 agonist increased microglial uptake of A $\beta .{ }^{6}$ In this study, however, EPRAP deficiency did not affect the amount of $\mathrm{A} \beta$, suggesting that this factor does not contribute to the EP4 signal associated with $A \beta$ clearance in microglia. EPRAP was identified as a novel protein associated with EP4 in macrophages, ${ }^{3}$ although our recent research suggests that the proinflammatory effects of EPRAP in microglia occur independent of $\mathrm{PGE}_{2}-\mathrm{EP} 4$ signaling. ${ }^{5}$ Furthermore, EPRAP is present throughout the whole cytoplasm in microglia, ${ }^{5}$ although EP4 localizes in a punctate perinuclear area in microglia. ${ }^{30}$ Indeed, the results of this study further support the notion that microglial EPRAP function is not associated with EP4 signaling in AD.

Drugs such as acetylcholinesterase inhibitors can improve cognitive function in patients with $\mathrm{AD}$, although such treatments cannot cure the disease. ${ }^{31}$ On the basis of the $A \beta$ cascade hypothesis, treatments have been developed that use $\gamma$-secretase inhibitors and antibodies against $A \beta$ peptide; however, clinical trials of these drugs have been wholly unsuccessful. $^{32,33}$ Therefore, further research regarding the pathogenesis of $A D$, not limited to suppressing $A \beta$, is urgently required. The results of this study suggest that EPRAP deficiency ameliorates brain inflammation and BPSD in patients with AD. The molecular mechanisms of BPSD are less well understood than those of the memory deficit in AD; however, treatment of BPSD is essential for improving quality of life for patients, decreasing the burden on caregivers, and minimizing medical expense. Further study is required to clarify the mechanisms underlying microglial activation via the EPRAP-related signaling pathway and to develop advanced therapies for the treatment of BPSD in patients with AD.
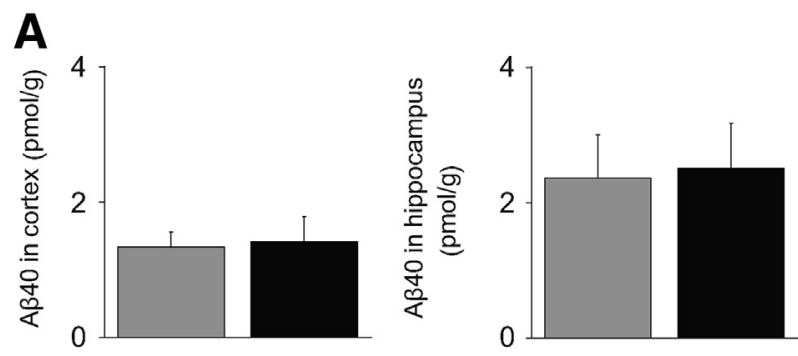

\section{B}
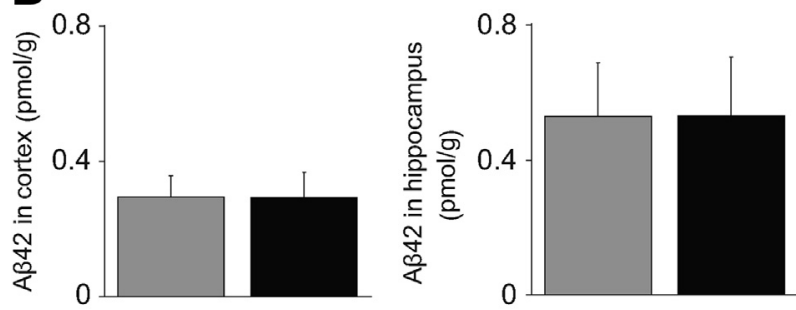

$\mathrm{J}^{20} 0^{+/-}$EPRAP $^{+/+}$

$\mathrm{J}^{2} 0^{+/-}$EPRAP $^{-1-}$

Figure 4 Prostaglandin $E_{2}$ type 4 receptor-associated protein (EPRAP) deficiency does not affect the amount of amyloid $\beta(A \beta)$. No significant differences in $A \beta$ levels were observed in the cortex (A) or hippocampus (B). Data are expressed as means \pm SEM. $n=6$ for each group. EPRAP ${ }^{-/-}$, EPRAP knockout; EPRAP $^{+/+}$, wild-type EPRAP; J20 ${ }^{+/-}$EPRAP $^{+/+}, \mathrm{J} 20$ transgenic with wild-type EPRAP; J20 ${ }^{+/-} \mathrm{EPRAP}^{-/-}$, J20 transgenic with EPRAP knockout. 
In summary, EPRAP deficiency suppresses microglial activation and reverses the reduced anxiety in $\mathrm{J} 20^{+/-}$mice. The reduced anxiety seen in J20 mice is not clearly compatible with human $\mathrm{AD}$, which is typically associated with increased anxiety; however, our results suggest that EPRAP may be related to the pathogenesis of AD. Further investigation may elucidate the role of EPRAP in the development and progression of human neurodegenerative diseases, as well as other health conditions.

\section{Acknowledgments}

We thank Dr. Masafumi Ihara and Satoshi Saito (National Cerebral and Cardiovascular Center Hospital, Suita, Japan) for their cooperation in generating compound mutant mice, Dr. Tsuyoshi Miyakawa (Fujita Health University, Toyoake, Japan) for his helpful advice on analyzing behavioral tests, Dr. Takahiro Masuda (University of Freiburg, Freiburg, Germany) for his helpful advice on immunostaining, Kazuo Nakanishi and Mariko Hayashi for their cooperation in behavioral experiments, and Erina Tajima and Yoshiko Fujiwara for their skilled technical assistance.

\section{References}

1. Heneka MT, Carson MJ, El Khoury J, Landreth GE, Brosseron F, Feinstein DL, et al: Neuroinflammation in Alzheimer's disease. Lancet Neurol 2015, 14:388-405

2. Stuchbury G, Munch G: Alzheimer's associated inflammation, potential drug targets and future therapies. J Neural Transm 2005, 112: 429-453

3. Takayama K, Sukhova GK, Chin MT, Libby P: A novel prostaglandin E receptor 4-associated protein participates in antiinflammatory signaling. Circ Res 2006, 98:499-504

4. Ventura-Holman T, Seldin MF, Li W, Maher JF: The murine fem1 gene family: homologs of the Caenorhabditis elegans sexdetermination protein FEM-1. Genomics 1998, 54:221-230

5. Fujikawa R, Higuchi S, Nakatsuji M, Yasui M, Ikedo T, Nagata M, Yokode M, Minami M: EP4 receptor-associated protein in microglia promotes inflammation in the brain. Am J Pathol 2016, 186: $1982-1988$

6. Woodling NS, Wang Q, Priyam PG, Larkin P, Shi J, Johansson JU, Zagol-Ikapitte I, Boutaud O, Andreasson KI: Suppression of Alzheimer-associated inflammation by microglial prostaglandin-E2 EP4 receptor signaling. J Neurosci 2014, 34:5882-5894

7. Nakatsuji M, Minami M, Seno H, Yasui M, Komekado H, Higuchi S, Fujikawa R, Nakanishi Y, Fukuda A, Kawada K, Sakai Y, Kita T, Libby P, Ikeuchi H, Yokode M, Chiba T: EP4 receptor-associated protein in macrophages ameliorates colitis and colitis-associated tumorigenesis. PLoS Genet 2015, 11:e1005542

8. Mucke L, Masliah E, Yu GQ, Mallory M, Rockenstein EM, Tatsuno G, Hu K, Kholodenko D, Johnson-Wood K, McConlogue L: High-level neuronal expression of abeta 1-42 in wild-type human amyloid protein precursor transgenic mice: synaptotoxicity without plaque formation. J Neurosci 2000, 20:4050-4058

9. Matsuo N, Takao K, Nakanishi K, Yamasaki N, Tanda K, Miyakawa T: Behavioral profiles of three C57BL/6 substrains. Front Behav Neurosci 2010, 4:29

10. Wright AL, Zinn R, Hohensinn B, Konen LM, Beynon SB, Tan RP, Clark IA, Abdipranoto A, Vissel B: Neuroinflammation and neuronal loss precede Abeta plaque deposition in the hAPP-J20 mouse model of Alzheimer's disease. PLoS One 2013, 8:e59586

11. Chin J, Palop JJ, Puolivali J, Massaro C, Bien-Ly N, Gerstein H, Scearce-Levie K, Masliah E, Mucke L: Fyn kinase induces synaptic and cognitive impairments in a transgenic mouse model of Alzheimer's disease. J Neurosci 2005, 25:9694-9703

12. Cheng IH, Scearce-Levie K, Legleiter J, Palop JJ, Gerstein H, BienLy N, Puolivali J, Lesne S, Ashe KH, Muchowski PJ, Mucke L: Accelerating amyloid-beta fibrillization reduces oligomer levels and functional deficits in Alzheimer disease mouse models. J Biol Chem 2007, 282:23818-23828

13. Holmgren S, Hjorth E, Schultzberg M, Larksater M, Frenkel D, TysenBackstrom AC, Aarsland D, Freund-Levi Y: Neuropsychiatric symptoms in dementia-a role for neuroinflammation? Brain Res Bull 2014, 108:88-93

14. Karl T, Bhatia S, Cheng D, Kim WS, Garner B: Cognitive phenotyping of amyloid precursor protein transgenic J20 mice. Behav Brain Res 2012, 228:392-397

15. Galvan V, Gorostiza OF, Banwait S, Ataie M, Logvinova AV, Sitaraman S, Carlson E, Sagi SA, Chevallier N, Jin K, Greenberg DA, Bredesen DE: Reversal of Alzheimer's-like pathology and behavior in human APP transgenic mice by mutation of Asp664. Proc Natl Acad Sci U S A 2006, 103:7130-7135

16. Hong S, Beja-Glasser VF, Nfonoyim BM, Frouin A, Li S, Ramakrishnan S, Merry KM, Shi Q, Rosenthal A, Barres BA, Lemere CA, Selkoe DJ, Stevens B: Complement and microglia mediate early synapse loss in Alzheimer mouse models. Science 2016, 352:712-716

17. Hebert LE, Weuve J, Scherr PA, Evans DA: Alzheimer disease in the United States (2010-2050) estimated using the 2010 census. Neurology 2013, 80:1778-1783

18. Tarkowski E, Andreasen N, Tarkowski A, Blennow K: Intrathecal inflammation precedes development of Alzheimer's disease. J Neurol Neurosurg Psychiatry 2003, 74:1200-1205

19. Heneka MT, Loschmann PA, Gleichmann M, Weller M, Schulz JB, Wullner U, Klockgether T: Induction of nitric oxide synthase and nitric oxide-mediated apoptosis in neuronal PC12 cells after stimulation with tumor necrosis factor-alpha/lipopolysaccharide. J Neurochem 1998, 71:88-94

20. Combs CK, Karlo JC, Kao SC, Landreth GE: beta-Amyloid stimulation of microglia and monocytes results in TNFalpha-dependent expression of inducible nitric oxide synthase and neuronal apoptosis. J Neurosci 2001, 21:1179-1188

21. Heneka MT, O'Banion MK, Terwel D, Kummer MP: Neuroinflammatory processes in Alzheimer's disease. J Neural Transm 2010, 117:919-947

22. Park SY, Jin ML, Kim YH, Kim Y, Lee SJ: Anti-inflammatory effects of aromatic-turmerone through blocking of NF-kappaB, JNK, and p38 MAPK signaling pathways in amyloid beta-stimulated microglia. Int Immunopharmacol 2012, 14:13-20

23. Perez Romero A, Gonzalez Garrido S: The importance of behavioural and pyschological symptoms in Alzheimer's disease. Neurologia 2016, [epub ahead of print] doi:10.1016/j.nrl.2016.02.024

24. Lalonde R, Fukuchi K, Strazielle C: APP transgenic mice for modelling behavioural and psychological symptoms of dementia (BPSD). Neurosci Biobehav Rev 2012, 36:1357-1375

25. Herrmann N: Recommendations for the management of behavioral and psychological symptoms of dementia. Can J Neurol Sci 2001, 28(Suppl 1):S96-S107

26. Zhu CB, Blakely RD, Hewlett WA: The proinflammatory cytokines interleukin-1beta and tumor necrosis factor-alpha activate serotonin transporters. Neuropsychopharmacology 2006, 31:2121-2131

27. Ballard C, Gauthier S, Corbett A, Brayne C, Aarsland D, Jones E: Alzheimer's disease. Lancet 2011, 377:1019-1031

28. Ivanov AD, Tukhbatova GR, Salozhin SV, Markevich VA: NGF but not BDNF overexpression protects hippocampal LTP from beta-amyloid-induced impairment. Neuroscience 2015, 289: $114-122$ 
29. Wang Y, Fu XT, Li DW, Wang K, Wang XZ, Li Y, Sun BL, Yang XY, Zheng ZC, Cho NC: Cyanidin suppresses amyloid beta-induced neurotoxicity by inhibiting reactive oxygen species-mediated DNA damage and apoptosis in PC12 cells. Neural Regen Res 2016, 11:795-800

30. Shi J, Johansson J, Woodling NS, Wang Q, Montine TJ, Andreasson K: The prostaglandin E2 E-prostanoid 4 receptor exerts anti-inflammatory effects in brain innate immunity. J Immunol 2010, 184:7207-7218

31. Steele LS, Glazier RH: Is donepezil effective for treating Alzheimer's disease? Can Fam Physician 1999, 45:917-919
32. Doody RS, Raman R, Farlow M, Iwatsubo T, Vellas B, Joffe S, Kieburtz K, He F, Sun X, Thomas RG, Aisen PS; Alzheimer's Disease Cooperative Study Steering Committee, Siemers E, Sethuraman G, Mohs R; Semagacestat Study Group: A phase 3 trial of semagacestat for treatment of Alzheimer's disease. N Engl J Med 2013, 369: $341-350$

33. Karran E, Hardy J: A critique of the drug discovery and phase 3 clinical programs targeting the amyloid hypothesis for Alzheimer disease. Ann Neurol 2014, 76:185-205 